\title{
PROBLEMS WITH RECTIFICATION OF HOIST SUPPORTS ON THE EXAMPLE OF A SEMI-PORTAL BRIDGE-CRANE WITH A LATTICE STRUCTURE
}

\begin{abstract}
The long period and conditions of operation are the cause of various types of severe damage to cranes used in the steelworks industry. Among the more dangerous and difficult to eliminate crane damage types, there is excess durable deflection of its supports from vertical axis. The object of the study is the semi-portal grab bridge-crane with steel lattice structure, for which deflection of a fixed support was detected that several times exceeded permissible values. For this crane, rectification was performed aimed at bringing fixed supports to the vertical line by stabilisation of the corrected location of the bearing structure of the crane using additional angle braces. The analysis of periodical geodetic measurements of the crane structure showed insufficient effect of the rectification, whereas loss of stability of some rods in the fixed support was detected. The study involved the FEM strength analysis of the crane, which revealed that the applied rectification method caused redistribution of forces in the rods of the fixed support, resulting in the loss of stability of some rods of the support, thus questioning the effectiveness of the rectification method applied.
\end{abstract}

Keywords: cranes, rectification, strength, FEM, operation

\section{PROBLEMY REKTYFIKACJI PODPÓR DŹWIGNIC NA PRZYKŁADZIE SUWNICY PÓŁBRAMOWEJ O KONSTRUKCJI KRATOWNICOWEJ}

\begin{abstract}
Dtugi okres eksploatacji oraz jej warunki sq przyczyna wystęowania różnych poważnych uszkodzeń suwnic stosowanych w przemyśle hutniczym. Jednym z groźniejszych i trudnych do wyeliminowania uszkodzeń suwnicy jest nadmierne trwate wychylenie jej podpór od pionu. Przedmiotem rozważań jest suwnica chwytakowa pótbramowa o konstrukcji stalowej kratownicowej, w przypadku której stwierdzono odchylenie podpory stałej od pionu, kilkakrotnie przekraczajace wartości dopuszczalne. Przeprowadzono rektyfikacje suwnicy, której celem byto doprowadzenie podpór statych do pionu przez zastabilizowanie skorygowanego położenia konstrukcji nośnej suwnicy z wykorzystaniem dodatkowych zastrzałów. Analiza prowadzonych okresowo pomiarów geodezyjnych konstrukcji suwnicy wykazała niezadowalajacy efekt przeprowadzonej rektyfikacji, przy czym jednocześnie stwierdzona zostata utrata stateczności niektórych prętów podpory stałej. W pracy wykonano analize wytrzymałościowa MES suwnicy, w której wykazano, ze zastosowana metoda rektyfikacji spowodowała redystrybucje sit w pretach podpory stałej skutkujacq wystapieniem utraty stateczności dla niektórych prętów podpory, stawiając jednocześnie pod znakiem zapytania skuteczność zastosowanej metody rektyfikacji.
\end{abstract}

Stowa kluczowe: suwnice, rektyfikacja, wytrzymatość, MES, eksploatacja

\section{INTRODUCTION}

Admission of a steelworks crane for operation is related to the need for meeting a number of requirements and performance of tests specified in standards (PN-M-45536:1997, PNM-45356:1988), as well as facility operating manual, whereas as regards to crane driving rails, requirements contained in standards (PN-M-45356:1988, ISO 8306:1985) must be met. In the case of cranes operated in the Polish steelworks industry in the longer time perspective, meeting of such requirements often faces difficulties that are usually related to significant wear, insufficient resources for maintenance, as well as damage to the structure that are difficult to eliminate. Among such damages, there is permanent deflection of supports from the vertical line According to (PN-M-45536:1997, PN-M-45356:1988) deflection of a fixed support with height $\mathrm{H}$ from vertical line should meet the following condition: $\Delta_{5} \leq H / 1000$, whereas at the same time $\Delta_{5} \leq 15 \mathrm{~mm}$.

The object of the analysis is a semi-portal grab bridgecrane operated in one of the Polish steelworks, with the hoist- ing capacity of $200 \mathrm{kN}$, with bolted lattice structure, made of S235JR grade steel, with geometry illustrated in figure 1. The static diagram of the crane is the single-span lattice frame with two supports of various length: long latticed support permanently connected with a rod, and a short self-aligning one with box structure. For the crane, deflection of the fixed support from the vertical line was detected towards the short support, with the values of 94 and $100 \mathrm{~mm}$ for both sides of the support, which many times exceeds permissible values.

\section{RECTIFICATION OF THE CRANE}

Adjustment of the geometric system of the lattice structure of the crane, involving bringing the fixed support to vertical position, was made on the basis of the rectification design developed on the basis of guidelines from the study (Flaga et al. 1994). For this purpose, a horizontal assembly balance lever has been designed with a turnbuckle in the form of a bottle screw, welded to front elements on the side of the self-aligning support, span structures of the neighbouring twin reloading bridges with the structure presented in figure 1 .

* AGH University of Science and Technology, Faculty of Mechanical Engineering and Robotics, Krakow, Poland, boglad@uci.agh.edu.pl 

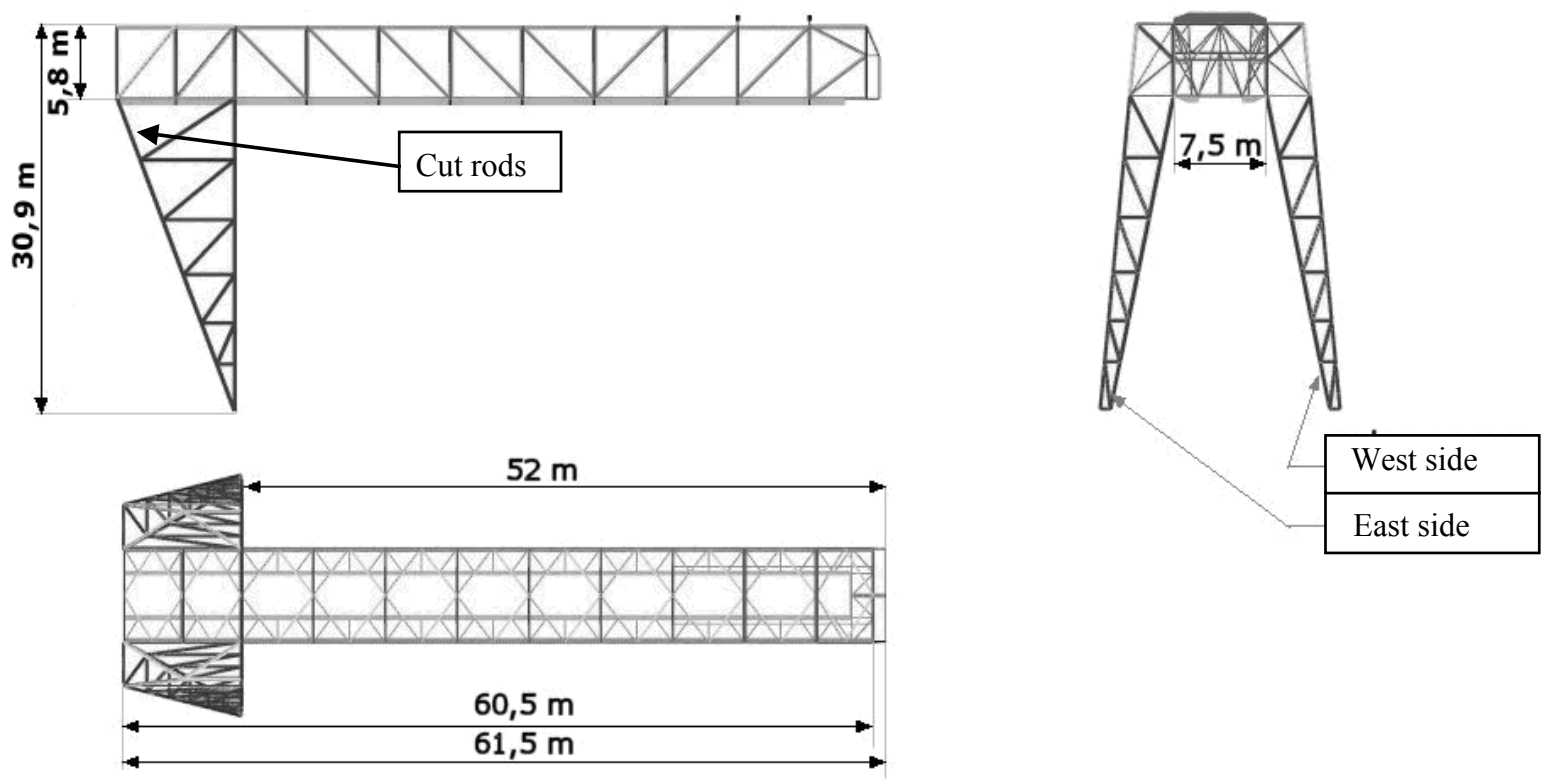

Fig. 1. Main crane dimensions

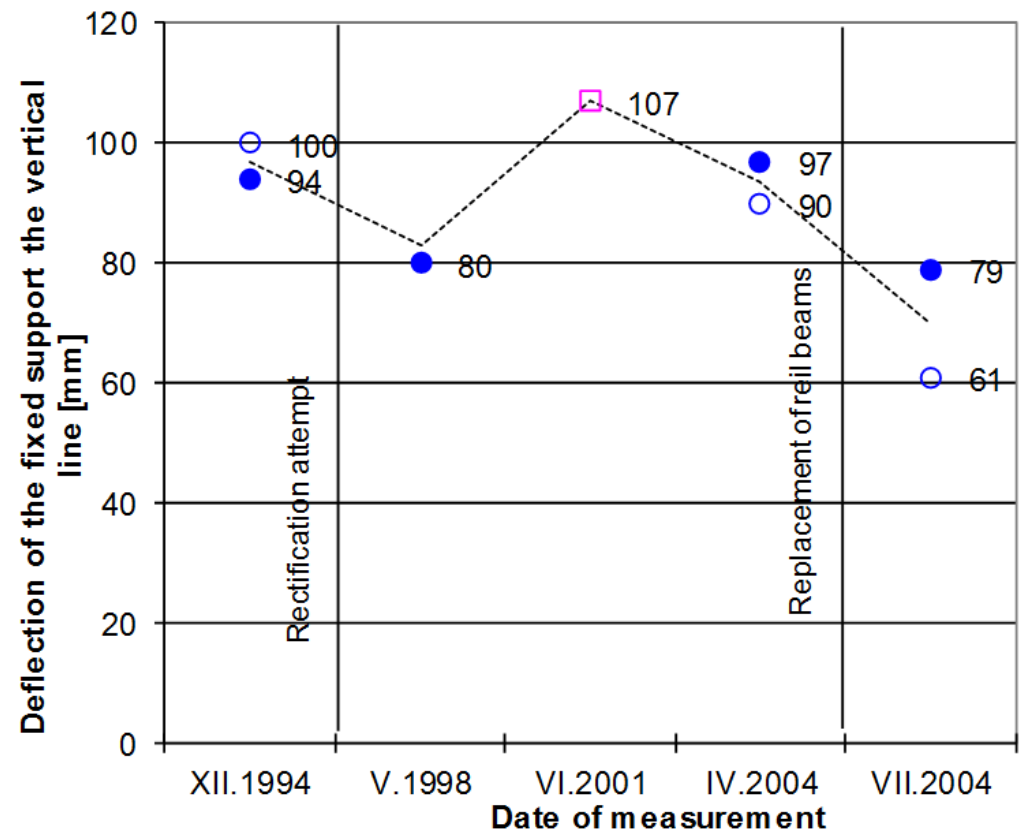

Description:

OFixed support from the west

- Fixed support from the east

$\square$ Fixed support in the joint axis

Fig. 2. Results of geodetic measurements of fixed support's deflection from vertical line (Ladecki et al. 2004) 
During the rectification performed using geodetic monitoring, six rods of the fixed support were cut and shortened within the area illustrated in figure 1, and then stabilisation of the adjusted position of the entire system was performed by the connection of the cut rods with the appropriate strengthening, and application of additional bracing using rods $\mathrm{K} 1$ and $\mathrm{K} 2$ (four rods in total), as illustrated in figure 4.

\section{RESULT OF THE RECTIFICATION}

Effects of the crane rectification performed can be assessed on the basis of geodetic measurements of fixed support deflection from vertical line (Ładecki et al. 2004), as illustrated in figure 2. The analysis of the measurement results listed indicates that for three measurement series performed after rectification (May 1998, June 2001 and April 2004), no significant reduction in the fixed support's deflection from vertical line was observed, as compared to the situation from before the rectification. The variability of fixed support deflection values in three aforementioned measurement series can be related to different positioning of the bridge at the rail length during consecutive measurements, impact of wind on the structure, as well as thermal conditions of the measurements.

Visible reduction to the support deflection by approx. $25 \%$ on average was recorded for measurements performed in July 2004 after the replacement of rail beams, whereas the deflection still exceeded permissible values several times. At the same time, crane overhauls carried out after the rectification pointed to the loss of stability of several rods of the fixed support, with deformation arrows of $5-30 \mathrm{~mm}$, as well as deformation in the area of some structural nodes. Deformations detected have been listed in table 1 (Ładecki et al. 2004).

The rectification, therefore, not only did not significantly contribute to the reduced deflection value of the fixed support from the vertical line, but also became the cause for the loss of stability for several rods of the fixed support. In order to explain the reasons for the situation, the relevant strength analysis was carried out using the finite elements method (FEM).

\section{FEM STRENGTH ANALYSIS OF THE CRANE}

The FEM strength analysis of the crane was performed using the FEEM Femap/NE Nastran kit (Eadecki et al. 2004, 2013, Niechwiej 2005). The developed beam-surface model of the structure, considering the permanent deflection of the fixed support from the vertical line with the value of $100 \mathrm{~mm}$ and inertia from bridge braking was loaded in the following variants: variant W1 - adopting specific weight of the carriage with the load set over the fixed support, and variant W2 - weight set at the centre of the span. The analysis involved two phases: for model M1 with geometry before the rectification (without additional bracing rods $\mathrm{K} 1$ and $\mathrm{K} 2$ ), and for model M2 after rectification, considering additional strengthening. Because for the support structure of the crane, according to the requirements of standard (PN-B-02005:1986), the value of the dynamic coefficient $\beta$ for the limit hoist capacity is adopted as equal to 1.3, thus for both variants additional FEM calculations were made considering increased loads by additional $30 \%$.

In order to assess the results of computer simulations of bridge operation, for all rods of the fixed support, relevant values of stability coefficients $\delta$ were calculated on the basis of standard (PN-EN 1993-1-1:2006) as: $\delta=N_{E d} / N_{b}, R_{d}$, where $N_{E d}$ is the calculated hoist capacity of the selected compressed rods, while $N_{b}, R_{d}$ is the hoist capacity for deformation of the compressed rod, specified according to [9], whereas $N_{E d} / N_{b}, R_{d} \leq 1$. The results of the FEM analyses indicated that the most unfavourable variant of loads for the fixed support is the W1 variant, for which specific weight of the carriage with load is set over the fixed support.

Table 1

Stability coefficient $\delta$ values and deformations determined

\begin{tabular}{|c|c|c|c|c|c|}
\hline \multirow{4}{*}{$\begin{array}{l}\text { Rod } \\
\text { No. } \\
\text { (fig. 3) }\end{array}$} & \multicolumn{4}{|c|}{ Stability coefficient $\delta=N_{E d} / N_{b}, R_{d}\left(N_{E d} / N_{b}, R_{d} \leq 1\right)$} & \multirow{4}{*}{$\begin{array}{l}\text { Permanent } \\
\text { deformation } \\
\text { detected with } \\
\text { arrow }[\mathrm{mm}]\end{array}$} \\
\hline & Model $N$ & ctification) & Model & ctification) & \\
\hline & \multicolumn{4}{|c|}{ Load version } & \\
\hline & W1 & $\mathrm{W} 1+30 \%$ & W1 & $\mathrm{W} 1+30 \%$ & \\
\hline 1 & \multirow{8}{*}{$<0.1$} & 0.11 & 0.48 & 1.25 & $25 \mathrm{~mm}$ \\
\hline 2 & & \multirow{7}{*}{$<0.1$} & 0.38 & 1.11 & $\begin{array}{c}5 \mathrm{~mm}+\text { node } \\
\text { deformation }\end{array}$ \\
\hline 3 & & & 0.4 & 0.91 & $30 \mathrm{~mm}$ \\
\hline 4 & & & 0.33 & 0.83 & $10 \mathrm{~mm}$ \\
\hline 5 & & & 0.32 & 0.67 & $10 \mathrm{~mm}$ \\
\hline 6 & & & 0.44 & 0.83 & $15 \mathrm{~mm}$ \\
\hline 7 & & & 0.42 & 0.91 & $13 \mathrm{~mm}$ \\
\hline 8 & & & 0.42 & 0.83 & $13 \mathrm{~mm}$ \\
\hline K1 & \multicolumn{2}{|c|}{-} & 0.56 & 1.11 & - \\
\hline $\mathrm{K} 2$ & \multicolumn{2}{|c|}{ - } & 0.56 & 1 & - \\
\hline
\end{tabular}




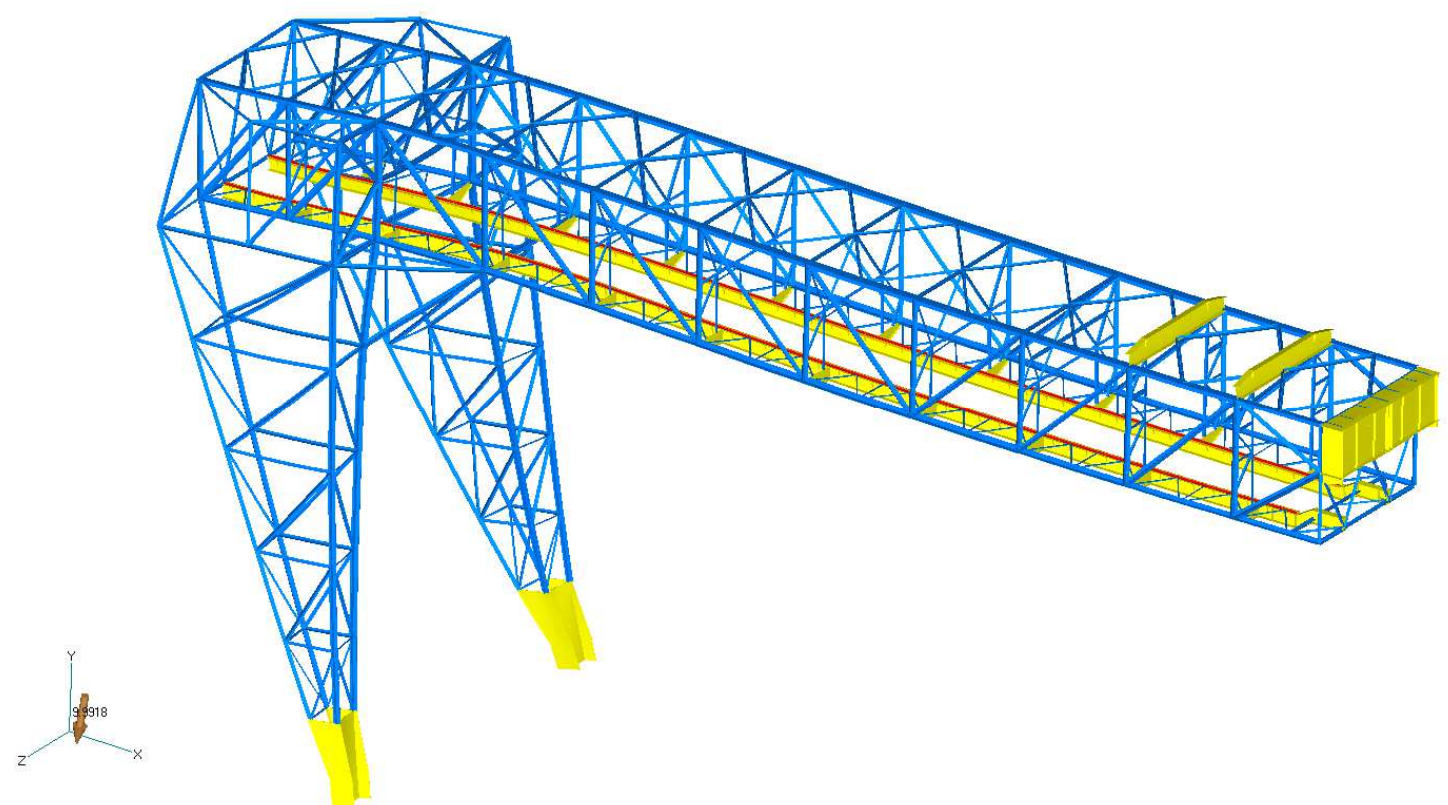

Fig. 3. Deformation of the bridge for model M2 with additional strengthening, load version W1, as obtained from FEM analysis

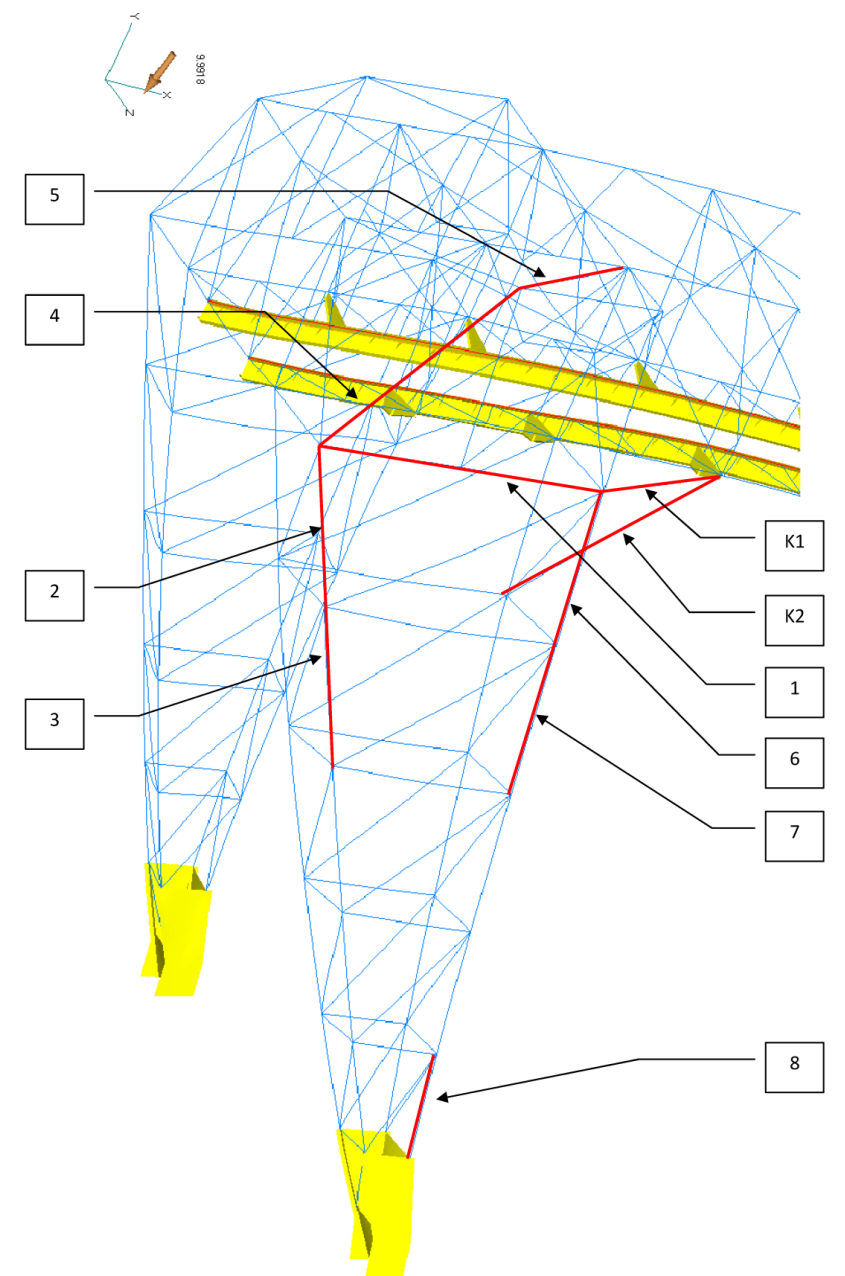

Fig. 4. Adopted numbering of the most stressed rods of the fixed support for model M2, load version W1 
An exemplary image of the crane deformation for the structure after rectification - model M2, for load version - W1 has been illustrated in figure 3 . The results of strength analysis performed have been listed in table 1, where for the most stressed rods of the fixed support, numbering of which has been shown in figure 4 , values of $\delta$ coefficients have been listed for load variant $\mathrm{W} 1$ and load variant $\mathrm{W} 1+30 \%$ (considering dynamic forces). The table also presents measured values of deformation arrows that appeared after crane rectification. The image of stability loss for rods No. 1 and 2, as obtained from FEM analysis, for the crane after rectification subjected to load $\mathrm{W} 1+30 \%$, has been illustrated in figure 5 .
The analysis of FEM calculation results listed in table 1 indicates that strengthening of the crane fixed support structure during the rectification with rods No. K1 and K2 caused redistribution of loads in rods of the support. Before rectification (model M1), both for load version W1, and for the version considering dynamic surplus $\mathrm{W} 1+30 \%$, the value of the stability coefficient $\delta$ met the requirements of standard (PN-EN 1993-1-1:2006) with significant reserve.

After rectification and installation of additional bracing rods (model M2), the value of stability coefficient $\delta$ for the most stressed rods is close to the permissible value, and for three rod sit even exceeded this value.

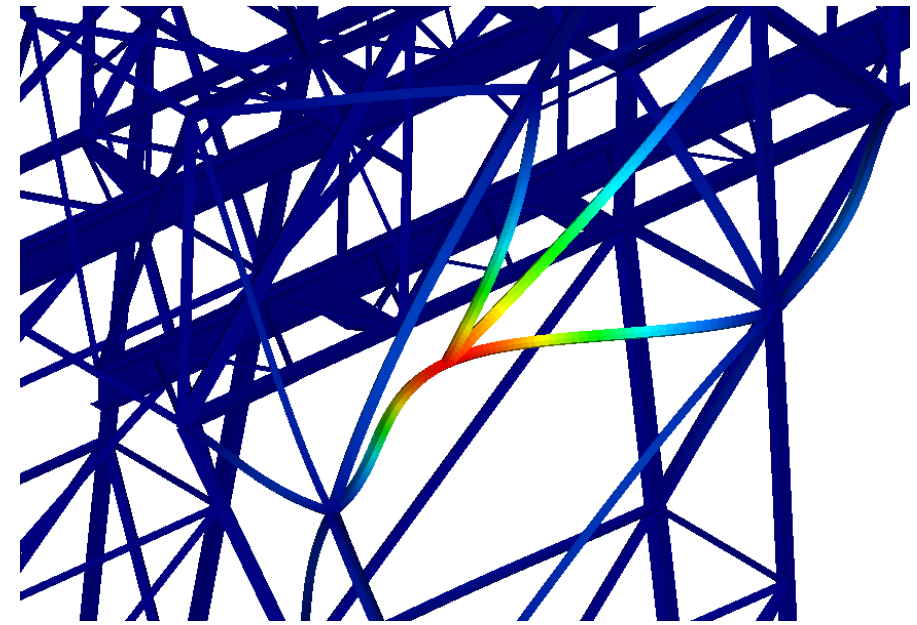

b)

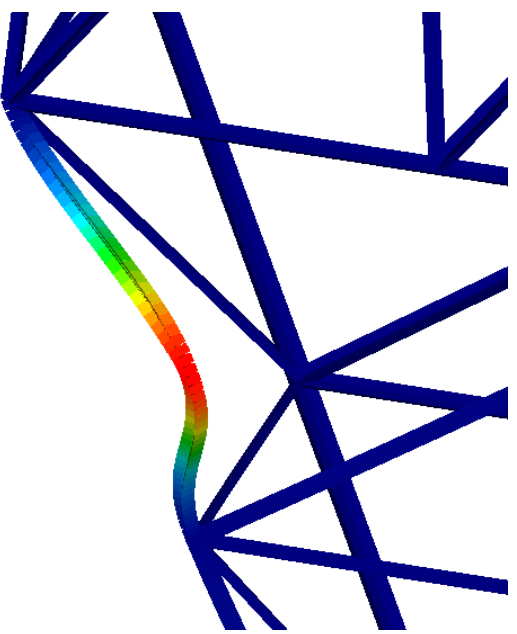

Fig. 5. Rod stability loss (FEM analysis: model - M2, load - W1+30\%): a) No. 1, b) No. 2

Despite the lack of awareness of the history of the crane's operating loads, the impact of prior repairs on rod loads, as well as a lack of exact data regarding actual loads on support rods after rectification, the Fem analysis clearly points to the fact that the cause for deformation of some rods of the crane's fixed support is the applied method of support rectification. Lack of determination of durable deformations for additional bracing rods $\mathrm{K} 1$ and $\mathrm{K} 2$ is probably related to the greater stiffness of the nodes in such rods, as well as the impossibility of accounting for other factors affecting redistribution of stresses in the fixed support structure after rectification.

\section{FINAL CONCLUSIONS}

Lack of significant reduction in the crane's fixed support deflection from the vertical line, determined with geodetic measurements after rectification, indicates that the proposed method for crane rectification did not bring the expected results, and even contributed to the deterioration of its technical condition due to the detected deformation of several rods of the fixed support. Safe operation of the crane with significant deflection of the fixed support from the vertical line is possible on condition of appropriate strengthening of the deformed rods, and on condition of regular monitoring of the bridge's technical condition, including geodetic measurements of the deformation of the crane's load bearing structure.
In view of the above, it can be stated that in the case of reloading bridges operated in the long time perspective with considerable deflection of the supports from the vertical line, it is possible to operate them safely, as confirmed by the fact of faultless operation of the crane discussed while observing the aforementioned conditions.

\section{References}

Flaga K., Furtak K. et al., 1994, Studium naukowo-badawcze oraz orzeczenie w sprawie możliwości $i$ warunków dalszej eksploatacji mostu czerpakowego $n r$ 2. PK IMiKB, Kraków.

Ładecki B., Cichociński A., Matachowski F., 2004, Ekspertyza techniczna mostu czerpakowego $n r$ 2. PREH Sp. z o.o., Kraków.

Ładecki B., Matachowski F., 2013, Analiza wytrzymałościowa suwnicy bramowej z btędami geometrii. AGH KWZMiK, Kraków, praca niepublikowana.

Niechwiej M., 2005, Analiza wytrzymatościowa konstrukcji mostu chwytakowego o udźwigu $200 \mathrm{kN}$. Praca magisterska, promotor B. Ładecki AGH, WIMiR, Kraków.

ISO 8306:1985, Cranes - Overhead travelling cranes and portal bridge cranes Tolerances for cranes and tracks.

PN-B-02005:1986, Obciqzenia budowli. Obciqzenia suwnicami pomostowymi, wciagarkami i wciagnikami.

PN-M-45356:1988, Dźwignice. Suwnice pótbramowe i bramowe. Wymagania i badania.

PN-M-45536:1997, Dźwignice. Suwnice hutnicze. Wymagania i metody badań. PN-EN 1993-1-1:2006, Eurokod 3: Projektowanie konstrukcji stalowych. Czesśc 1-1: Reguty ogólne i reguty dla budynków. 